\title{
Food waste valorization through composting and bio-drying for small scale fruit processing agro-industries
}

INGENIERÍA AMBIENTAL

\section{Valorización de pérdidas de alimentos mediante compostaje y biosecado para pequeñas agroindustrias procesadoras de}

frutas

\author{
Laura Brenes-Peralta $^{18}$, María F. Jiménez-Morales ${ }^{1 \oplus}$, Rooel Campos-Rodríguez ${ }^{1(i)}$ \\ ${ }^{1}$ Tecnologico de Costa Rica, Agribusiness School/Escuela de Agronegocios \& Agroforestry Academic \\ Area/Área Académica Agroforestal, Cartago, Costa Rica \\ \$labrenes@tec.ac.cr,maria.jimenez@tec.ac.cr,rocampos@tec.ac.cr
}

Recibido: 6 de mayo de 2020 - Aceptado: 08 de septiembre de 2020

\begin{abstract}
Agri-food industries entail a relevant economic activity, with major opportunities to improve food security, the economy, and the environmental performance of food systems. However, those opportunities can be challenged by Food Waste (FW), since estimates suggest that 55\% of certain groups of food products, such as fruits and vegetables are lost or wasted along the food supply chain. The Latin American and Caribbean region is one of the most relevant in the world supply of fruits, based in a high number of small-scale farmers and agri-processors. Strategies that aid in better management of FW consider the recovery and recycling of still valuable materials from the waste. In consequence, this study focused on comparing technical parameters of four biowaste treatments, to valorize the FW that is originated by small fruit-processing agroindustry in the Latin American country of Costa Rica. The main results indicate that the Takakura-type composting method in tumblers presents appropriate technical conditions to valorize this type of $\mathrm{FW}$, due to the obtention of compost for potential use in agricultural or gardening. The biodrying alternative will aid in case the treated waste needs to be stored or transported for further uses or disposal since it is a stabilized material, hence less weight, and humidity content, and potentially fewer emissions are expected. However, the observed conditions of this study, indicate it is not advisable to use this later directly as a soil amendment since the temperatures reached during the experiment might not assure the inactivation of possibly present pathogens.
\end{abstract}

Keywords: Agro-industry, Bio-drying, Biowaste, Composting, Valorization.

\section{Resumen}

La industria agroalimentaria encierra una importante actividad económica, con grandes oportunidades para contribuir a la seguridad alimentaria, la economía y el desempeño ambiental de los sistemas alimentarios. Sin embargo, la 
pérdida y desperdicio de alimentos (PDA) representa un reto para esas oportunidades, ya que hay estimados que indican que el $55 \%$ de ciertos grupos de productos agroalimentarios, como las frutas y vegetales, se pierden o desperdician a lo largo de las cadenas de suministro. La Región de Latinoamérica y el Caribe es una de las más relevantes en el suministro mundial de frutas, y sostiene su producción sobre una amplia base de pequeños productores y procesadores de alimentos. Las estrategias que apoyan una mejor gestión de las PDA consideran la recuperación y el reciclaje de materiales aún valiosos presentes en estos residuos. En consecuencia, este estudio se enfocó en comparar los parámetros técnicos de cuatro tratamientos de residuos orgánicos, para valorizar las PDA originadas por una pequeña agroindustria procesadora de frutas de un país latinoamericano como es Costa Rica. Los principales resultados indicaron que el compostaje tipo takakura en tómbolas presentó condiciones técnicas apropiadas para valorizar este tipo de PDA, debido a la obtención de un compost de uso potencial en agricultura o jardinería. La alternativa de biosecado podría ayudar en caso de que el residuo tratado deba ser almacenado o transportado para otros usos o disposición final ya que es un material estabilizado; por tanto, pesa menos, contiene menos humedad y se esperaría que generara menos emisiones. Sin embargo, las condiciones observadas en el estudio indicaron que no sería recomendable su uso directamente como enmienda de suelo, dado que las temperaturas alcanzadas durante el experimento podrían no asegurar la inactivación de posibles patógenos presentes.

Palabras clave: Agroindustria, Biosecado, Bioresiduo, Compostaje, Valorización.

\section{Introduction}

The agri-food sector is recognized as relevant in society, due to its role in food security and nutrition, and its paramount impacts on the economy, health, and environment ${ }^{(1)}$. The food supply should be doubled by 2050 to meet the demand that will be caused by the expected growth of the population ${ }^{(2)}$, hence growth opportunities for the sector are predictable. However, several challenges related to climate change, market trends, waste generation, intensity on energy requirements ${ }^{(3)}$, and food supply management threaten the sustainability of agri-food systems.

One particular challenge is Food Losses and Waste, present in the agenda of national governments and international organizations, but still with evidence that needs to be addressed in terms of research, governance, and implementation ${ }^{(1)}$. According to the HPLE ${ }^{(4)}$, food losses and waste are defined as "a decrease, at all stages of the food chain from harvest to consumption, in mass, of food that was originally intended for human consumption, regardless of the cause". In a wider view, being this the definition adopted in this paper, the EU FP7 project FUSIONS defined Food Waste (FW) as "any food, and inedible parts of food, removed from the food supply chain to be recovered or disposed of (including composted, crops plowed in/not harvested, anaerobic digestion, bioenergy production, co-generation, incineration, disposal to sewer, landfill or discarded to sea)" (5). FW causes tremendous effects in the economy of food systems, as well as in the environment and food supply ${ }^{(6)}$.

Estimations suggest that one-third of the world food production is lost or wasted each year, while 820 million people suffer from hunger or malnutrition ${ }^{(7)}$. FW is also responsible for 1 billion USD economic losses ${ }^{(8)}$, the waste of 250 $\mathrm{km}^{3}$ of water per year, and the emission of $4.4 \mathrm{Gt}$ of $\mathrm{CO}^{2}$ eq ${ }^{(9)}$. The FW quantity varies from one region to another, and causes are explained due to productivity, climate and cultural conditions, knowledge, investment and technology access, regulations, market standards, and demographics, among many others. Major studies indicate a generation of $\mathrm{FW}$ that ranges from 63 to 103 million tons per year in the United States of America, 89 million tons per 
year in Europe, and 127 million tons per year in Latin America and the Caribbean ${ }^{(3)}$.

The fruits and vegetables agri-food sector discard $55 \%$ of its production along the supply chain ${ }^{(6)}$. Parfitt, Barthel, \& Macnaughton ${ }^{(10)}$ pointed an estimate of $16 \% \mathrm{FW}$ in the foodprocessing sector in the United Kingdom, while FAO ${ }^{(6)}$ indicates a $6 \% \mathrm{FW}$ in the same sector of the Latin American and Caribbean Region. Regardless of the differences among sectors and regions, the impact in the profitability of the entrepreneurs developing these activities, the environmental effects caused by the waste generation, the embodied resources mismanagement, and the constrains inaccessible safe and nutritious food available for consumers, deserve attention ${ }^{(10)}$.

Interventions at any of the possible levels should be evidence-based; something that led to the evaluation of methodologies to assess FW, as well as studies regarding possible actions to prevent and reduce $\mathrm{FW}^{(11-13)}$.

Regarding developments to tackle FW, those in the Latin American and Caribbean Region are of interest due to its high contribution to the world food supply. International statistics indicate that $14 \%$ of the global production comes from this region ${ }^{(14)}$, and potentially, this implies also a relevant contribution in the FW amount. Therefore, FW began to be addressed more systematically in 2014, and some first case studies began explaining the situation in countries like Costa Rica ${ }^{(15,16)}$. Research in this country has also focused on food waste management and valorization, with techniques such as composting, anaerobic digestion, and animal feed production from the restaurant and domestic kitchens food waste ${ }^{(17-19)}$.

Current trends directing towards circularity propose less resource extraction while a more intensive recirculation of those already extracted occurs within the economic systems (20). Accordingly, Target 12.3 of the Sustainable Development Goals aims to halve food waste by 2030 , embracing a hierarchy that moves from most to least desirable actions ${ }^{(13)}$. Prevention is the utmost preferred alternative followed by optimization, and finally, recycling and recovery options are favored before landfill disposition, when waste is unavoidably generated ${ }^{(4,21)}$.

There are different methods to achieve the recycling and recovery of still valuable resources from FW, such as biorefinery, anaerobic digestion, composting, and bio-drying. Composting consists of the degradation of biowaste through controlled conditions (temperature and $\mathrm{pH}$ among the most relevant parameters to control) ${ }^{(22)}$; and as a result, it will produce a substrate known as compost. There are different techniques to produce compost, and within those, the Takakura method, based on the use of inoculated substrates, has shown increased quality and efficiency results compared to other composting methods ${ }^{(19)}$.

On the other hand, bio-drying is similar to composting, with the difference that this bioprocess focuses on the reduction of water from the waste ${ }^{(23)}$ through the metabolic heat produced by the exothermic microbial activity and aeration of the waste mass. The degradation, in this case, is only partial, and as a result, the waste mass is reduced and stabilized. This could allow easier transportation, as well as fewer possibilities of leaching and emissions if stored before alternative uses or even disposal. Once the waste is dried, it can be used directly as a substrate or as a combusting input depending on the original waste characteristics ${ }^{(24)}$.

In this study, the authors placed their attention on the problem of non-valorized FW generated by small-scale fruit processors, since they play a key role in the Costa Rican and Latin American and Caribbean economy ${ }^{(25)}$. The main goal was 
to evaluate four $\mathrm{FW}$ valorization treatments, based on composting and bio-drying, which can result in technically feasible options for small agro-industries while presenting potential from the environmental and implementation perspectives. In consequence, this paper aims to consider an alternative FW treatment method for a small fruit-processor, similar to the business scale and activity as others in the country and Region.

\section{Methodology}

This case study took place at the campus of Tecnológico de Costa Rica, in the Cartago Province, located at the east of the Costa Rican Central Valley, during 2019, in alliance with a local Small and Medium Enterprise (SME) called Viva Concentrados S.A. This latter was interested in exploring different $\mathrm{FW}$ reduction and treatment alternatives; therefore, the researchers used the FW derived from the processing of different fruits in this company and validated the studied alternatives through the establishment of a Food Waste Valorization Team (FWVT). This group integrated the researchers as well as the Production and General Managers of the company in an effort to address FW in this context. The study entailed both experimental trials and qualitative assessments to finally fulfill the aim of the study regarding the consideration of technically feasible and alternative FW treatments for this small fruit-processor.

\subsection{Experimental design}

The research was executed through a factor experimental design in order to compare four FW treatments as described in Table 1, with two repetitions each. The FW consisted of a representative mixture of residues of one week of fruit processing (strawberry Fragaria sp, soursop Annona muricata, pineapple Ananas comosus, and cas Psidium friedrichsthalium). A particular amount and type of substrate was added to the waste depending on each treatment, on day 1 of the experiment.

The waste and substrate masses were mixed twice a day and data collection included 19 observations to monitor technical parameters.

Table 1. Description of treatments*

\begin{tabular}{|c|c|c|c|}
\hline Treatment & Code & Repetition & Description \\
\hline $\begin{array}{l}\text { Takakura } \\
\text { composting in } \\
\text { a mechanical } \\
\text { tumble } \\
\text { composter }\end{array}$ & $\mathrm{TKT}$ & $\begin{array}{l}\mathrm{R} 1 \\
\mathrm{R} 2\end{array}$ & $\begin{array}{l}\text { The treatment used } \\
30 \mathrm{~kg} \text { of FW with } \\
10 \mathrm{~kg} \text { of inoculated } \\
\text { substrate (note } 1 \text { ). }\end{array}$ \\
\hline $\begin{array}{l}\text { Conventional } \\
\text { FW+ Wood } \\
\text { Pellets } \\
\text { composting in } \\
\text { a mechanical } \\
\text { tumble } \\
\text { composter }\end{array}$ & PT & $\begin{array}{l}\mathrm{R} 1 \\
\mathrm{R} 2\end{array}$ & $\begin{array}{l}\text { The treatment used } \\
30 \mathrm{~kg} \text { of FW with } 6 \\
\mathrm{~kg} \text { of wood pellets } \\
\text { as substrate or } \\
\text { structuring material, } \\
\text { as indicated by the } \\
\text { local supplier. }\end{array}$ \\
\hline $\begin{array}{l}\text { Takakura } \\
\text { composting } \\
\text { pile (on the } \\
\text { ground) }\end{array}$ & TKS & $\begin{array}{l}\mathrm{R} 1 \\
\mathrm{R} 2\end{array}$ & $\begin{array}{l}\text { The treatment used } \\
30 \mathrm{~kg} \text { of FW with } \\
10 \mathrm{~kg} \text { of inoculated } \\
\text { substrate (note } 1 \text { ). }\end{array}$ \\
\hline $\begin{array}{l}\text { Bio-drying pile } \\
\text { (on the } \\
\text { ground) }\end{array}$ & BS & $\begin{array}{l}\mathrm{R} 1 \\
\mathrm{R} 2\end{array}$ & $\begin{array}{l}\text { The treatment used } \\
30 \mathrm{~kg} \text { of FW with a } \\
\text { substrate of } 7,5 \mathrm{~kg} \\
\text { of wood chips as } \\
\text { structuring material, } \\
\text { obtained at the } \\
\text { campus after usual } \\
\text { tree pruning. }\end{array}$ \\
\hline
\end{tabular}

*This substrate consisted of an inoculated mixture of fermented solutions and solid materials such as rice husk, charcoal, semolina, and mulch following the method cited by Campos-Rodríguez and authors ${ }^{(29)}$.

\subsection{Data analysis}

The monitored technical variables consisted of physio-chemical variables such as temperature, $\mathrm{pH}$, and humidity. The researchers conducted a variance analysis to statistically compare the obtained data, once the normality of data was tested by applying the Tuckey test (p-value of $0,05)$ and using the Infostat $\left({ }^{\circ}\right.$ software. A comparative matrix was created to summarize the mentioned variables and two additional attributes regarding the potential degradation of the FWW (non-stabilized, partially- stabilized, 
stabilized, degraded), and the expected microbiological quality of the obtained product about the pathogen status (pathogens inactivated, pathogens not inactivated).

Finally, a validation session with the FWVT allowed the exchange and considerations from the economic and environmental standpoint, based on experts' criteria, for the obtained results of the experiment. The session entailed a meeting where members analyzed the results of the experiment and interacted following the prepared semi-structured questionnaire for this purpose, which consisted of three main criteria to discuss: a) simplicity of the treatment, b) required space, and equipment, c) use of treated FW. The output of these analyses would result in the conclusion of most technically feasible FW treatments for the SME.

\section{Results and discussion}

\subsection{Temperature}

Both repetitions of the TKT, PTR and TKS treatments presented the typical behavior of a composting process (Figure 1), with temperatures belonging to the four known stages of these type of process: mesophilic phase (20 to $35^{\circ} \mathrm{C}$ ), thermophilic phase $\left(35\right.$ to $\left.65^{\circ} \mathrm{C}\right)$, cooling phase; and curing phase ${ }^{(26)}$. The BS treatment, presented a different behavior, as expected for not being a full degradation technique such as composting.

TKTR1, TKTR2 and PTR1 reached the thermophilic phase earlier in the experiment, while the action of thermophilic microorganisms in PTR2 was detected at the fourth observation and the fifth observation for TKSR1 and TKSR2. TKT treatments presented the highest temperature, followed by TKS and finally, the PT treatments presented its highest thermophilic. The BS treatment (BSR1 and BSR2) reached a thermophilic phase during the third and fourth observation respectively, with their highest temperatures considerably different from the other treatments.

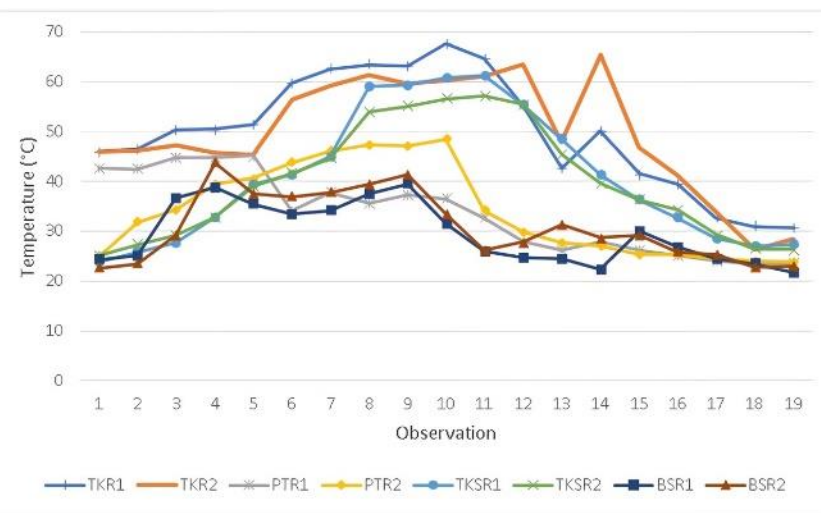

Figure 1. Evolution of the temperature in the $F W$ treatments

Differences between PTR1 and PTR2 can be attributed to diverse FW composition, due to possible heterogeneity in the sample. Both repetitions of TKT and TKS presented differences during the first days of the experiment among themselves, which could be attributed to different mixing techniques (the FW mixing process in the tumbling composter of TKT could result in a more uniform mix than in the composting pile of TKS); as well as to differences in the composting infrastructure (the closed tumble-composter can avoid heat dispersion while composting piles tend to equilibrium with the environmental conditions, hence heat dispersion can be higher), as already observed in the experiments by Chaves-Arias et al in $2019^{(17)}$.

The temperature of BSR1 and BSR2 is lower than the temperature of the rest of the treatments, because of the infrastructure and removal technique similar to in TKS treatments, but also to the technique, environmental conditions, and consistency of the mixture. Colomer et al (27), explained that the relation of temperature and airflow in the waste matrix of a bio-drying system is a decisive factor; therefore, the wood 
chips, together with the technique and the environmental airflow could have affected the oxygen availability, and consequently the metabolic action of the microorganisms in this case.

TKT (repetitions R1 and R2) presented the longest thermophilic period, recorded in 16 of the 19 observations. TKS (R1 and R2) remained in that phase during 11 observations and PTR1 for 10 observations, while PTR2 only for seven of the 19 observations of the experiment. The BS treatment presented a thermophilic observation in seven (R1) and six (R2) observations during the experiment. The average thermophilic temperature for each treatment is presented in Table 2. The TKT treatment reached the highest average thermophilic temperatures throughout the experiment as well as the highest thermophilic temperatures, followed by TKS, PT, and BS.

It is relevant to specify that TKT and TKS used an inoculated substrate as indicated by the Takakura composting method, which provided a set of microorganisms that acted faster and more properly in the FW matrix of this case ${ }^{(28)}$. This influenced the internal conditions of the treatment allowing longer and faster thermophilic activity, as observed in other similar experiments, such as the one presented by Chaves-Arias, et al ${ }^{(17)}$. Both PT and BS treatments used structuring material with lower microbial content (wood pellets and wood chips respectively).

The variance analysis of the temperature indicates there are statistical differences ( $p$ $<0,0001$ ), between the takakura composting alternatives (TKT and TKS) and the bio-drying alternative (BS). Statistical differences are attributable to the amount and type of organisms present in the TK treatments, which also results in a longer thermophilic phase, in contrast to BS treatment which had up to $17^{\circ} \mathrm{C}$ less than the other cases.
Table 2. Average thermophilic temperature of FW treatments.

\begin{tabular}{ccc}
\hline Treatment & $\begin{array}{c}\text { Mean } \\
\text { thermophilic } \\
\text { temperature }\left({ }^{\circ} \mathbf{C}\right)\end{array}$ & S.D $( \pm)$ \\
\hline TKTR1 & 53.40 & 9.11 \\
TKTR2 & 53.33 & 8.12 \\
PTR1 & 40.09 & 4.28 \\
PTR2 & 44.70 & 3.56 \\
TKSR1 & 49.77 & 9.58 \\
TKSR2 & 47.68 & 8.05 \\
BS1 & 36.46 & 2.31 \\
BS2 & 39.45 & 2.67 \\
\hline
\end{tabular}

There were no significant differences between PT and TK treatments $\left(9^{\circ} \mathrm{C}\right.$ maximum $)$ supported by the effect of proper mixing and removal techniques in the microbiologic activity (as presented in the tumbling composter). These results can be seen in Figure 2.

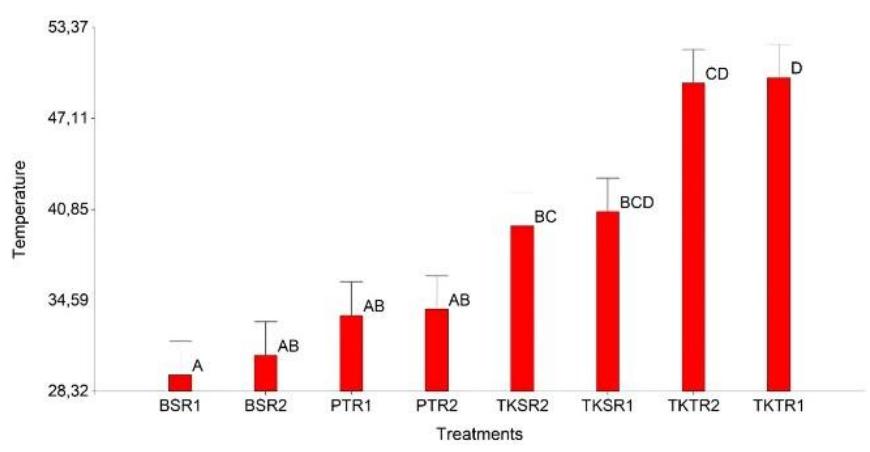

Figure 2. Comparative variance analysis for the temperature of the four $F W$ treatments (same letters indicate there are no statistical difference

\subsection{Humidity}

This variable decreased throughout the experiment (Figure 3). The humidity content in compost may have two origins: initial humidity content of the waste and the released water of the microbial metabolic activity. The changes in this parameter are a result of the characteristics of the waste to be degraded and the composting technique ${ }^{(17)}$. Pile composting methods should also consider environmental conditions, and 
when these do not influence directly in the process, humidity content will vary because of evaporation caused by the temperature rise due to the metabolic activity of microorganisms in the system.

The BS and TKS treatment presented the most intense decrease trend. Since it was set in piles, the non-confined disposition of the treatment allowed improved evaporation or dissipation of moisture, as suggested by Arrigioni in $2011^{(31)}$. Even when the other pile treatment (BS) shared that disposition, the microbial inoculum was not the same as in the TKS. In contrast, PT and TKT were in enclosed structures which prevented the moisture to be easily evaporated.

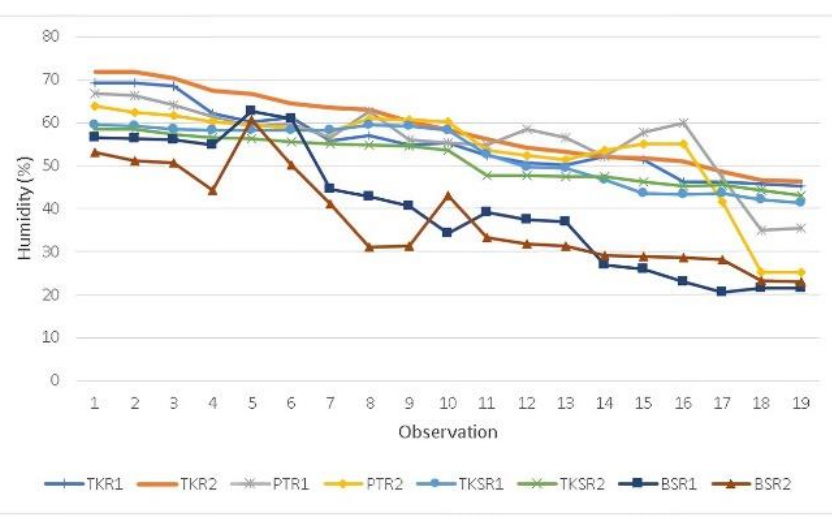

Figure 3. Evolution of the humidity content in the $F W$ treatments

The TKT, PT, and TKS treatments presented an average humidity above $50 \%$, while BS had average humidity contents beneath that threshold (Table 3). TKT and PT remained with a humidity content of $50 \%$ for a longer period, while TKS presented humidity percentages beneath $50 \%$ after the twelfth observation of the experiment, and BS after the seventh. In order to promote proper microbial action to degrade $\mathrm{FW}$ as expected in a composting method, humidity is recommended to be at a range of 50-70\% during the process and particularly in the thermophilic phase, while it will decrease together with the decrease of temperature (cooling phase of composting) ${ }^{(17,26)}$.
Table 3. Mean humidity content and humidity gradients of the FW treatments

\begin{tabular}{ccc}
\hline Treatment & $\begin{array}{c}\text { Mean Humidity } \\
\text { content }(\boldsymbol{\%})\end{array}$ & S.D $( \pm)$ \\
\hline TKR1 & 55.44 & 7.87 \\
TKR2 & 58.80 & 8.53 \\
PTR1 & 56.03 & 8.71 \\
PTR2 & 53.64 & 11.26 \\
TKSR1 & 52.59 & 7.14 \\
TKSR2 & 51.30 & 5.35 \\
BSR1 & 40.12 & 14.43 \\
BSR2 & 37.56 & 11.28 \\
\hline
\end{tabular}

BS, even with less temperature, presented less humidity content at the end of the experiment, possibly due to less moisture released by microbial metabolism in the system, supporting the aim of bio-drying in terms of moisture content reduction to facilitate further management of the waste and not complete degradation. TKS treatment presented higher humidity mean and more days above the recommended $70 \%$ maximum humidity; which caused leaching, a non-desired condition (Figure 4).

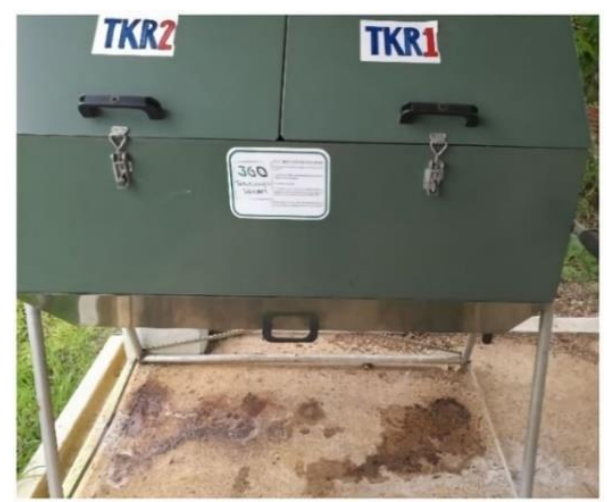

Figure 4. Leaches formed during the TKT experiment in tumble composters

The statistical analysis for the humidity variable is presented in Figure 5, where the significative differences $(p<0,0001)$ between bio-drying (BS) alternatives and composting alternatives (TKT, TKS, and PT) are observed. No statistical differences were observed among each pair of repetitions. 


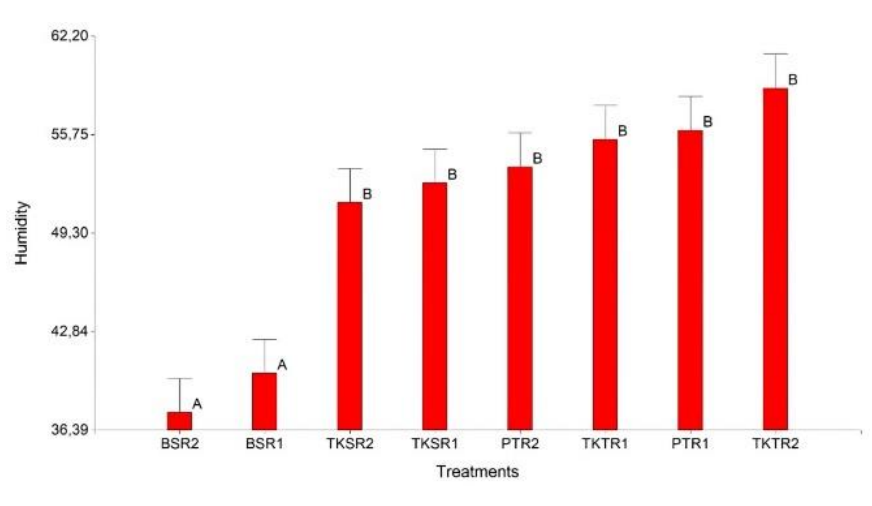

Figure 5. Comparative variance analysis for the humidity variable of the four $F W$ treatments (same letters indicate there are not statistical difference same letters indicate there are no statistical difference)

\section{3. $\mathrm{pH}$}

The results regarding the $\mathrm{pH}$ variable are observed in Figure 6, where the four FW treatments presented lower $\mathrm{pH}$ at the beginning of the process, which increased during the experiment and tended to neutrality towards the end. BS, designated as BSR1 and BSR2 in the following figure, presented earlier alkalization of the treated FW mass and remained above a $\mathrm{pH}$ value of 7 .

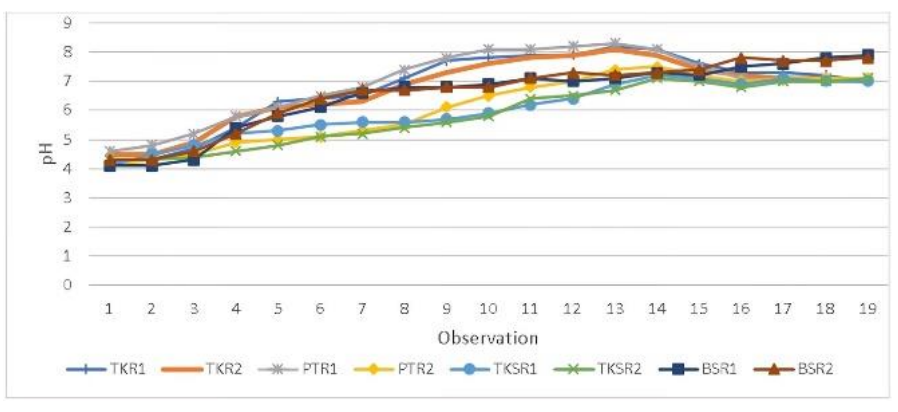

Figure 6. Evolution of the $p H$ the FW treatments

Besides the initial $\mathrm{pH}$ of the $\mathrm{FW}$ of this particular experiment, which was low (from 4.1 to 4.5 depending on the homogeneity of the sample), the evolution of the $\mathrm{pH}$ variable in biowaste degradation methods is explained in the three phases: the first and more acid stage will entail the release of organic acids because of the action of microorganisms in the waste; this was observed in the four treatments. Then an alkalization process will be observed in the second phase due to the decrease in organic acids and the appearance of ammonia after the degradation of proteins and nitrogen-based compounds; as seen in the four treatments as well. Finally, the $\mathrm{pH}$ will tend to neutrality in the third phase due to the formation of humic compounds; this did not occur with the BS treatments, potentially because of less microbial activity that did not influence the creation of humic compounds ${ }^{(29)}$.

This evolution, together with humidity are relevant to explain the FW degradation processes, while the temperature will relate to pathogens inactivation as well. Moreover, monitoring the $\mathrm{pH}$ evolution can also indicate proper aeration conditions in the process. Since the present microorganisms are aerobic, a significant decrease in the $\mathrm{pH}$ will indicate the presence of anaerobic conditions that would release more organic acids and consequently produce a $\mathrm{pH}$ value beneath $7^{(17)}$.

The statistical variance analysis for $\mathrm{pH}$ is presented in Figure 7, where the different treatments and repetitions are observed (same letters indicate there are not differences). Figure 7 suggests there are no statistical differences among the alternatives of FW valorization since $\mathrm{pH}$ fluctuations among treatments were low.

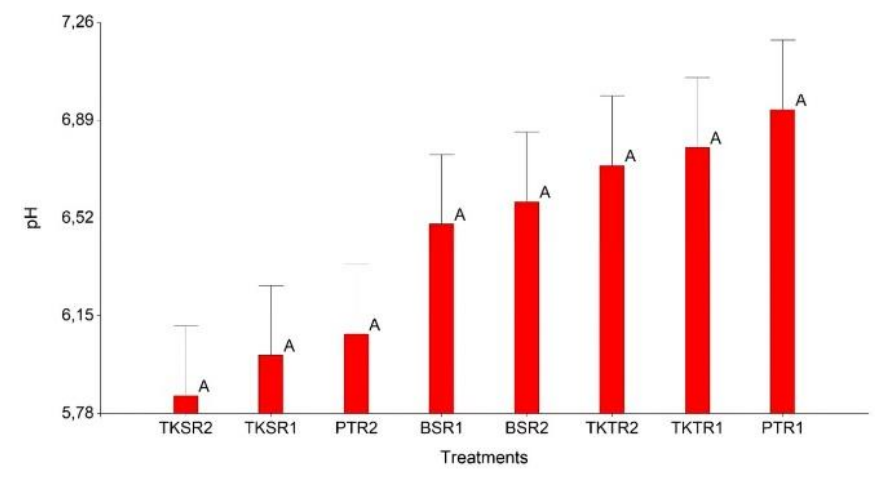

Figure 7. Comparative variance analysis for the $p H$ value of the four $F W$ treatments 


\subsection{Comparative matrix and implications for agro-industrial facilities}

The different alternatives were analyzed regarding the technical variables and inferred attributes to consider their feasibility as FW treatment for a small agro-industry, and the results are summarized in Table 4; which entails a brief description of the results of each variable per treatment.

The results suggest all treatments have technically appropriate $\mathrm{pH}$ and humidity ranges, however, temperature, hence pathogen inactivation is not the same for the four treatments. This latter is a critical aspect according to Tortarolo et al. ${ }^{(30)}$, who indicate that optimal temperature ranges in this type of treatments are essential to guarantee an effective degradation of the biowaste; since it has been proven that even small variations in the temperature will have higher effects on the microbial activity to degrade biowaste, than changes in humidity, $\mathrm{pH}$ or Carbon-Nitrogen $(\mathrm{C} / \mathrm{N})$ relations. Thermophilic temperatures above $35^{\circ} \mathrm{C}$ and close to $55^{\circ} \mathrm{C}$ or higher for at least 15 days, will also guarantee the inactivation pathogenic microorganisms, which is crucial in case the degraded biowaste is planned to be used as soil fertilizer or substrate.

The validation exercise within the FWVT, provided considerations regarding the fact that both approaches (composting or bio-drying) seemed simple and accessible for this type of business; however, space is usually a limitation and cross-contamination could be a risk, particularly in the food industry. In consequence, the tumble alternatives as PT and TKT would seem more appropriate, since they established outside a safe perimeter of the facilities (closer to the ordinary waste collection point, for example). Those alternatives would have to consider the investment in the composting tumblers. Regarding the use of the treated FW, the company would not use it directly in their activities, but its associates or surrounding community could perceive a benefit from the obtained product. In this case, the composting alternatives would be of interest. Nevertheless, if no direct users are found, bio-drying could be easier to transport to other facilities, or even for landfill disposal, entailing less mass, volume,

Table 4. Comparative technical matrix of $F W$ treatments

\begin{tabular}{llllll}
\hline $\begin{array}{c}\text { Variable or } \\
\text { attribute }\end{array}$ & \multicolumn{1}{c}{ TKT } & \multicolumn{1}{c}{ TKS } & \multicolumn{2}{c}{ PT } & \multicolumn{1}{c}{ BS } \\
\hline $\begin{array}{l}\text { Mean } \\
\text { thermophilic } \\
\text { temperature }\end{array}$ & $\begin{array}{l}\text { Above } \\
50^{\circ} \mathrm{C} \text { for } \\
\text { more than } \\
15 \text { days }\end{array}$ & $\begin{array}{l}\text { Above } 50^{\circ} \mathrm{C} \text { for } \\
\text { less than } \\
15 \text { days }\end{array}$ & $\begin{array}{l}\text { Less } 50^{\circ} \mathrm{C} \\
\text { than }\end{array}$ & $\begin{array}{l}\text { Less than } \\
50^{\circ} \mathrm{C}\end{array}$ \\
\hline $\begin{array}{l}\text { Final Humidity } \\
\text { content }\end{array}$ & $\begin{array}{l}\text { More than } \\
40 \%\end{array}$ & $\begin{array}{l}\text { More than } \\
40 \%\end{array}$ & $\begin{array}{l}\text { More than } \\
30 \% \text { and less } \\
\text { than 40\% }\end{array}$ & $\begin{array}{l}\text { Less than } \\
30 \%\end{array}$ \\
\hline $\begin{array}{l}\text { Final pH values } \\
\text { Between } 7\end{array}$ & $\begin{array}{l}\text { Between } 7 \\
\text { and } 7.1\end{array}$ & $\begin{array}{l}\text { Between } 7 \text { and } \\
7.1\end{array}$ & $\begin{array}{l}\text { Between } \\
7.8 \text { and } 7.9\end{array}$ \\
\hline $\begin{array}{l}\text { Potential FW } \\
\text { Degradation } \\
\text { status }\end{array}$ & Degraded & Degraded & Stabilized & $\begin{array}{l}\text { Partially } \\
\text { stabilized }\end{array}$ \\
\hline $\begin{array}{l}\text { Expected } \\
\text { microbiological } \\
\text { quality of } \\
\text { valorized FW }\end{array}$ & $\begin{array}{l}\text { Pathogens } \\
\text { potentially } \\
\text { inactivated }\end{array}$ & $\begin{array}{l}\text { Pathogens } \\
\text { Non- } \\
\text { inactivated }\end{array}$ & $\begin{array}{l}\text { Pathogens } \\
\text { Non- } \\
\text { inactivated }\end{array}$ & $\begin{array}{l}\text { Pathogens } \\
\text { Non- } \\
\text { inactivated }\end{array}$ \\
\hline
\end{tabular}


and emissions. However, since bio-drying is foreseen in piles, space and cross-contamination were a constrain that would have to be observed, unless an alternative FW treatment area can be located elsewhere and not in close by areas of the plant.

\section{Conclusions}

According to the main goal of evaluating FW treatment alternatives that were technically feasible, the TKT alternative presented more desirable variables and attributes to treat this type of FW, since the reached temperatures and duration of those, as well as the $\mathrm{pH}$ values, would suggest the FW was degraded and most pathogens would be potentially inactivated. The statistical analysis of the results also presents this alternative as similar to the other composting techniques, and quite dissimilar to the bio-drying in all the technical parameters that were evaluated. The obtained product can be used as a soil enhancer or substrate in other activities, suggesting an improved environmental perspective, while also being relatively easy to implement for the SME.

Even when there were little differences with other composting techniques, the rest of the treatments could not guarantee the inactivation of pathogens; therefore, even when the FW was degraded (fully in TKT, stabilized in PT, or partially stabilized in BS), the obtained product would not be appropriate as substrate or soil fertilizer since it may cause disease in crop production or gardening. However, an important consideration would be that the four alternatives could guarantee fewer emissions, odors, leaches, or vectors propagation since the degradation process can be inferred from the monitored variables. Finally, in the case of BS, it will present the less humidity content, making it easier for the temporary storage or transportation of the final mass.
The fact that the SME currently disposes of the FW through municipal services does not represent in compliance with the current laws; however, this traditional disposition does not represent a valorization of the waste, while the alternatives presented in this study will not only empower the SMEs to take direct actions over the FW generation but even obtain valuable materials for further activities or alliances with high environmental commitment. This last opportunity is widely funded in an innovative perspective brought from the bio-economy and circular economy principles that seek the completion of loops, the decoupling of economic growth from exhaustive resource extraction, and degradation. Even when only a few national plans or proposals for formal bio-economy policies are currently observed in the region, SMEs hold great potential to innovate to become more sustainable.

Finally, the proposed methodological approach that began with the assessment of the valorization treatments through specific technical factors (temperature, humidity content, and $\mathrm{pH}$ ), and the later validation with an interdisciplinary team, allows SMEs to move towards more science-based decisions, with the support of the experience of professionals that also allow considering the specific context where this possible valorization would be implemented.

Further research could promote the consideration of FW valorization models and the study of different factors, their relation, and their effect on the valorized product. Other research would be required to determine if $\mathrm{BS}$ would be fit for other known purposes of bio-dried wastes, such as combustion. Moreover, additional experimentation regarding a more frequent removal of the waste, pre-treatment such as free water drainage or particle homogenizing of the FW could present evidence to improve the FW treatment alternatives, and other considerations regarding cost, complexity, spatial requirements, 
and knowledge should be included to determine the adaptability of one alternative or another for small agro-industries.

\section{Acknowledgments}

The authors would like to recognize the contribution of Arlyn García Salas during the execution of the experiment, as well as for the support of the Research and Extension ViceRectory of Tecnológico de Costa Rica through funding under project no.1431012. Special gratitude is also extended to the personnel of Viva Concentrados S.A, and managers, as well as to the staff of the Soils Laboratory of the National Institute of Agricultural Innovation and Technology Transference -INTA and the Agribusiness School personnel from the Agriculture experimentation center CPDIA.

\section{Funding Statement}

The author(s) received no specific funding for this work.

\section{References}

(1) Mink P, Faes D, Solon MM, Vaart N van der, editors. Sustainable Food Systems for All - Catalyzing Change through Multi-Stakeholder Action. In: 1st Global Conference of the 10YFP Sustainable Food Systems (SFS) Programme. Pretoria, South Africa; 2017.

(2) Accorsi R, Manzini R, editors. Sustainable Food Supply Chains Planning, Design, and Control through Interdisciplinary Methodologies. 1st ed. Elsevier Academic Press; 2019. 394 p.

(3) Vittuari M, Menna F De, García-Herrero L, Pagani M, Brenes-Peralta L, Segrè A. Food systems sustainability: The complex challenge of food loss and waste. In: Accorsi R, Manzini R, editors. Sustainable Food Supply Chains Planning, Design, and Control through
Interdisciplinary Methodologies. 1st ed. Elsevier Academic Press; 2019. p. 24960.

(4) HLPE - FAO. Food losses and waste in the context of sustainable food systems [Internet]. 2014. (HLPE Reports series). Report No.: 8. [cited 2020 March 16]. Available from: http://www.fao.org/3/ai3901e.pdf.

(5) Östergren K, Gustavsson J, SIK (The Swedish Institute for Biotechnology and Food), Bos-Brouwers H, Timmermans T, Wageningen UR, et al. FUSIONS Definitional Framework for Food Waste [Internet]. Borås, Sweden; 2014 [cited 2020 Feb 26]. Available from: https://www.eu-

fusions.org/phocadownload/Publications/ FUSIONS Definitional Framework for Food Waste 2014.pdf.

(6) FAO. Boletín Pérdidas y Desperdicio de Alimentos en América Latina y el Caribe [Internet]. Santiago de Chile; 2014 [cited 2020 Mar 10]. Available from: http://www.fao.org/3/a-i3942s.pdf.

FAO. The State of Food Security and Nutrition in the World 2019 Safeguarding against economic slowdowns and downturn [Internet]. Rome; 2019 [cited 2020 Mar 10]. Available from: http://www.fao.org/3/ca5162en/ca5162en .pdf.

(8) FAO. Food Loss and Food Waste [Internet]. Policy Support and Governance Gateway. 2016 [cited 2020 Mar 10]. Available from: http://www.fao.org/policysupport/policy-themes/food-loss-foodwaste/en/. 
(9) FAO. FAO and the SGFs, Indicators: Measuring up to the 2030 Agenda for Sustainable Development [Internet]. Rome; 2017 [cited 2020 Mar 10]. Available from: http://www.fao.org/3/ai6919e.pdf.

(10) Parfitt J, Barthel M, Macnaughton S. Food waste within food supply chains: quantification and potential for change to 2050. Philos Trans R Soc B. 2010;365(1554):3065-81. https://doi.org/10.1098/rstb.2010.0126.

(11) WRI, CGF, FAO, UNEP, WRAP, WBCSD. Food Loss and Waste Accounting and Reporting Standard. Rome; 2016 [cited 2020 March 10]. Available from: https://www.wbcsd.org/Programs/Foodand-Nature/Food-Land-Use/ClimateSmart-Agriculture/Resources/Food-Lossand-Waste-Accounting-and-ReportingStandard.

(12) Corrado S, Caldeira C, Eriksson M, Jørgen-Hanssen O, Hauserd H-E, Holsteijn $F$ van, et al. Food waste accounting methodologies: Challenges, opportunities, and further advancements. Glob Food Sec. 2019;20:93-100. https://doi.org/10.1016/j.gfs.2019.01.002.

(13) FAO. Boletín Pérdidas y Desperdicios de Alimentos en América Latina y el Caribe [Internet]. Rome; 2017 [cited 2020 Feb 18]. Available from: http://www.fao.org/3/a-i7248s.pdf.

(14) OECD/FAO. Agricultural Outlook 20192028. Paris: OECD Publishing; 2019.

(15) Brenes-Peralta L, Jimenez-Morales MF, Gamboa-Murillo M. Diagnóstico de Pérdidas y Desperdicio Alimenticio en dos canales de comercialización de la Agrocadena de Tomate Costarricense para su posterior Disminución [Internet]. Cartago, Costa Rica; 2015. Available from: http://hdl.handle.net/2238/6458.

(16) Brenes-Peralta L, Campos-Rodríguez R, Jimenez-Morales MF, Gamboa-Murillo M. Aprovechamiento de residuos sólidos orgánicos: oportunidad para un sistema alimentario e institución sostenibles. InvestigaTEC. 2017;(29):22-4.

(17) Chaves-Arias R, Campos-Rodríguez R, Brenes-Peralta L, Jiménez-Morales MF. Compostaje de residuos sólidos biodegradables del restaurante institucional del Tecnológico de Costa Rica. Rev Tecnol En Marcha. 2019;32(1):39-53.

https://doi.org/10.18845/tm.v32i1.4117.

(18) Ávila-Hernández M, Campos-Rodríguez R, Brenes-Peralta L, Jiménes-Morales MF. Generación de biogás a partir del aprovechamiento de residuos sólidos biodegradables en el Tecnológico de Costa Rica, sede Cartago. Rev Tecnol En Marcha. 2018;31(2):159-70. https://doi.org/10.18845/tm.v31i2.3633.

(19) Ramírez-Ramírez F, Campos-Rodríguez R, Jiménez-Morales MF, Brenes-Peralta LP. Evaluación técnica, ambiental y económica de tres tipos de tratamiento para el cultivo de lechuga en huertas caseras de Guácimo, Limón, Costa Rica. Rev Tecnol En Marcha. 2016;29(8):1424.

https://doi.org/10.18845/tm.v29i8.2981.

(20) Corona B, Shen L, Reike D, Carreón JR, Worrell E. Towards sustainable development through the circular economy-A review and critical assessment on current circularity metrics. 
Resour Conserv Recycl.

2019;151:104498.https://doi.org/10.1016/

j.resconrec.2019.104498.

(21) Papargyropoulou E, Lozano R, Steinberger JK, Wright N, Ujang Z bin. The food waste hierarchy as a framework for the management of food surplus and food waste. J Clean Prod. 2014;76:10615.https://doi.org/10.1016/j.jclepro.2014. 04.020 .

(22) Borrero-González G, Arias-Aguilar D, Campos-Rodríguez R, PachecoRodríguez F. Comparative study on the use of two substrates with microbial inoculants for organic solid waste domestic composting. Rev Tecnol En Marcha. 2015;29(1):28-37. https://doi.org/10.18845/tm.v29i1.2536.

(23) Rodríguez EMS, Morales RB, Martínez FR. Biosecado en invernaderos de residuos sólidos orgánicos. In: XII Congreso Nacional de Biotecnología y Bioingeniería. Morelia, Michoacán; 2009.

(24) Contreras-Cisneros RM, Robles-Martínez F, Franco-Hernández MO, Piña-Guzmán AB. Efecto de Residuos sólidos orgánicos biosecados en el crecimiento de lechuga. In: VII Simposio Iberoamericano en Ingeniería de Residuos Hacia una economía circular. Santander, España: REDISA; 2017. p. 420-4.

(25) CEPAL. Banca de desarrollo y pymes en Costa Rica [Internet]. Santiago de Chile; 2009. (Serie Financiamiento del desarrollo). Report No.: 209. [cited 2020 March 10]. Available from:https://repositorio.cepal.org/bitstrea m/handle/11362/5185/1/S0900127_es.pdf
(26) Bueno-Bosch M. Cómo hacer un buen compost: manual para horticultores ecológicos. 5th ed. España: FERTILIDAD DE LA TIERRA; 2010. $170 \mathrm{p}$.

(27) Colomer FJ, Herrera L, Gallardo A, Bovea MD, Robles F. El biosecado como proceso biológico para minimizar la humedad de residuos de jardinería. In: XV Congreso Internacional de Ingeniería de Proyectos. Huesca, España; 2011. p. 948-66.

(28) Jiménez-Antillón J, Calleja-Amador C, Romero-Esquivel LG. Food Waste Recovery with Takakura Portable Compost Boxes in Offices and Working Places. Resources. 2018;7(4):84. https://doi.org/10.3390/resources7040084

(29) Campos-Rodríguez R, Brenes-Peralta LP, Jiménez-Morales MF. Evaluación técnica de dos métodos de compostaje para el tratamiento de residuos sólidos biodegradables domiciliarios y su uso en huertas caseras. Rev Tecnol En Marcha. 2016;29(8):25-32. https://doi.org/10.18845/tm.v29i8.2982.

(30) Tortarolo MF, Pereda M, Palma M. Influencia de la inoculación de microorganismos sobre la temperatura en el proceso de compostaje. Cienc del suelo. 2008;26(1):41-50.

Arrigoni JP. Evaluación del Desempeño de Diferentes Prototipos de Compostadores en el Tratamiento de Residuos Orgánicos [dissertation]. Buenos Aires: Universidad Nacional del Comahue; 2011. 